\title{
OF LAME DUCKS, BLACK SHEEP AND FAMILY BONDING
}

\section{ONE CENTURY OF THE WILL-MAKING DUTIES OF A COMMONWEALTH FATHER}

\author{
Sheena Grattan, Senior Lecturer in Law, Queen's University of \\ Belfast*
}

\section{INTRODUCTION}

From the perspective of the succession lawyer there can have been few more significant statutory innovations throughout the Commonwealth during the century which has just ended than the "flexible restraint on testamentary freedom", the phrase first coined by Professor Laufer as a generic term for the type of legislation which will no doubt be most familiar to the present readership as the Inheritance (Provision for Family and Dependants) (Northern Ireland) Order 1979, and the Inheritance (Provision for Family and Dependants) Act 1975, its virtually identical English counterpart. Indeed, such family protection legislation, to introduce another accepted generic label (the one which will be employed throughout this paper), is as old as that century itself, having been pioneered by New Zealand, then the "social laboratory of the world", ${ }^{1}$ in the form of the Testator's Family Maintenance Act 1900 at its very dawn. Within forty years legislation adapted to local variations and rejoicing in a wide variety of names (for example, "dependant's relief", "family provision" and "will variation" legislation), but broadly adopting the seminal structure of this New Zealand prototype had been introduced to Australia and $\mathrm{Canada}^{2}$ and, following a prolonged parliamentary struggle, to England. ${ }^{3}$ By the latter half of the century similar

* The author would like to thank Professor Gareth Miller, University of East Anglia, for the comments he made on the draft of this article.

1 During the twenty-one years in which the New Zealand Liberal Party was in power (1891-1912) New Zealand initiated a programme of legislative reform, the creativity and extent of which far belied the country's size and population. Other legislation enacted included the Factories Act 1891, the Employer's Liability Act 1891, the Industrial Conciliation and Arbitration Act 1894 and the Old Age Pensions Act 1898.

2 In Australia: Victoria - Widows and Young Children Maintenance Act 1906 (since replaced by Victoria Administration and Probate Acts 1928 and 1958); Tasmania Testator's Family Maintenance Act 1912; Queensland - Testator's Family Maintenance Act 1914 (since replaced by Part IV of the Succession Act 1981); New South Wales - Testator's Family Maintenance and Guardianship of Infants Act 1916 (since replaced by the Family Provision Act 1982); South Australia Testator's Family Maintenance Act 1918 (since replaced by Inheritance (Family Provision Act 1972); Western Australia - Testator's Family Maintenance Act 1939 (since replaced by the Inheritance (Family and Dependants) Act 1972); ACT - Part VIII of the Administration and Probate Ordinance 1929; and Northern Territories Testator's Family Maintenance Ordinance 1929.

3 The Inheritance (Family Provision) Act 1938, since replaced by the Inheritance (Provision for Family and Dependants) Act 1975. For a good account of the 
enactments had spread to yet more of the English speaking world, including both Irish jurisdictions, ${ }^{4}$ and beyond. ${ }^{5}$

As the century closed, family protection legislation, "succession by arbitration", had unquestionably established itself as a third "pillar" of the traditionally bi-partite succession edifice (that is, the rules of testate and of intestate succession); a far cry from the observation once made by Lord Reid, when interpreting the provisions of an Act of 1882, that it was "inconceivable" that Parliament should have put the whole of a man's capital at the discretion of a judge! ${ }^{6}$ It is thus rather surprising that family protection legislation, which has done exactly that, has provoked relatively little academic discussion or debate - at least in this part of the world. ${ }^{7}$ It would be unfortunate if the centenary of this genus of legislation were to pass without some assessment being made of the impact which it has made. An all-embracing review is beyond the scope of a single article, so the focus of this paper has been limited to one particularly influential strand of Commonwealth jurisprudence, namely the analysis of the family protection jurisdiction in terms of the breach of a moral duty owed to an applicant by the testator.

\section{THE MORAL DUTY TEST CONCEIVED}

" It is the duty of the Court, so far as possible, to place itself in all respects in the position of the testator, and to consider whether or not, having regard to all existing facts and surrounding circumstances, the testator has been guilty of a manifest breach of that moral duty which a just, but not a loving, husband or father owes towards his wife or towards his children, as the case may be". ${ }^{8}$

When Edwards J of the New Zealand Court of Appeal first pronounced these now familiar words back in 1910 in the course of his judgment in Allardice $\mathrm{v}$ Allardice, the learned judge probably had little reason to suspect that they would become what is arguably the most oft-quoted judicial dictum in the history of family succession law, or that he had just spawned what Laufer would later christen "the reasonable man of the law of domestic relations". ${ }^{9}$

parliamentary background, see Tyler's Family Provision (third ed, RD Oughton, 1997).

${ }^{4}$ In Northern Ireland the Inheritance (Family Provision) Act (NI) 1960, since repealed and replaced by the Inheritance (Provision for Family and Dependants)(NI) Order 1979. In the Republic s117 of the Succession Act 1965. This latter provision extends only to the testator's children. A parallel fixed share system protects the spouse (s 111 of the 1965 Act).

5 Eg Israel - chapter 4 of the Succession Law 1965.

6 Cited in S Cretney, "Discretion or Whim, Freedom of Choice or Caprice?" (1986) 6 OJLS 299.

7 A comment which is valid of succession law in general in the United Kingdom. See, eg, the comments made by Professor Miller in his preface to The Machinery of Succession, (2nd ed, 1996). The same has not been true of succession issues in other parts of the Commonwealth, such as New Zealand.

8 Per Edwards J in Re Allardice; Allardice v Allardice (1910) 29 NZLR 959 at 972973.

9 J Laufer, "Flexible Restraints on Testamentary Freedom" (1955) 69 Harvard Law Review 277 at 295. 
Since then a not insignificant number of the world's judiciary have been assiduously rectifying what they have deemed to be breaches of moral duty by will-makers from many varied social and ethnic backgrounds, as Edwards J's test evolved into the benchmark for judicial intervention in the discretionary family protection systems of Australasia, Canada and the Republic of Ireland. Amongst these the Republic of Ireland stands unique to the author's knowledge the only jurisdiction in the world to enshrine Edwards J's hypothetical creature in statute. ${ }^{10}$ Elsewhere, however, the absence of statutory recognition has not thwarted the ambitions of this juristic person; he, and his morality, have succeeded in influencing the concept of testamentary freedom far beyond anything which a mere "judicial gloss"11 might have aspired to. By the 1970's and the 1980's it seemed that the years might be taking their toll as the judicious father and husband came under the microscope of a number of Commonwealth law reform agencies. The prognosis was mixed, but he generally survived to fight another day. As a new century begins, however, it seems that time may finally be running short for this judge-made creation, for if the draft Succession (Adjustment) Act is enacted by the New Zealand Parliament he will be expunged by statute from his homeland, which may possibly herald the slippery slope towards global extinction.

It is thus appropriate that the aim of this article is two-fold. Its first purpose is to explore and assess the impact which Allardice has had in shaping family succession within the Commonwealth in the course of the last ninety years. An appraisal of how the decision has affected the full range of family members (for example, widow, widower, and infant children) is beyond the scope of this work, so, for reasons which are explained below, the analysis will be limited to one particular family member, the adult child. Secondly, in light of the proposals for legislative reform made recently by the New Zealand Law Commission it is a timely evaluation of how significant the breach of moral duty test should remain in the twenty-first century. Neither task, however, can be properly undertaken without some understanding of the function(s) which family protection legislation is designed to perform. Before, then, we turn to consider the Allardice decision and its legacy more closely, a brief reminder of the history, nature and objectives of this particular legislation may be helpful.

\section{FLEXIBLE RESTRAINTS ON TESTAMENTARY FREEDOM -} THE BACKGROUND

New Zealand's Testator's Family Maintenance Act 1900 had purported to provide a novel solution to a problem which was as old as private property

10 Succession Act 1965, s117, which empowers the testator's children to apply for an award out of their parents' estate. Since 1967 the term "moral duty" has also appeared, but not centrally, in the New Zealand legislation: the Family Protection Amendment Act 1967 amended s 3(2) of the Family Protection Act 1955 by prescribing certain matters which must be considered by the Courts in assessing the testator's "moral duty" to his grandchildren (grandchildren being eligible applicants under this Act).

11 From time to time members of the Commonwealth judiciary have reminded their colleagues that Edwards J's just husband and father is a mere gloss on the statute. A selection of these cases is noted below. 
and society itself, namely how best to ensure that weak and vulnerable members of a person's family were afforded adequate economic protection from that person's estate after his death. While legal theorists have disagreed on emphasis few have disputed that one of the functions of the law of succession in a civilised society is the preservation and protection of the family. ${ }^{12}$ Indeed, the law of succession has been described as "an attempt to define the family in terms of property."13

The precise relationship between inheritance structures and the concepts of both "family" and "property" is obviously highly complex, not least because it is an ever-changing one. For the purposes of this article, however, it can be taken to be broadly the case that prior to New Zealand's pioneering legislation the function of protecting the family was delivered, virtually universally, by means of rigid and inviolable rules ${ }^{14}$ whereby both beneficiaries and the extent of their benefit were precisely defined, so that a set portion was guaranteed to persons who could claim to be within a certain legal relationship to the deceased (historically most often his children and rather less frequently his wife). ${ }^{15}$

Just over one hundred years ago Professor Ely observed that "at a rash guess nineteen-twentieths of the human beings who have ever lived" have also duly died in the sure and certain knowledge that all their worldly goods would thereafter be allocated strictly in accordance with a prescribed order, totally irrespective of any personal wishes which they might have had. ${ }^{16}$ The intervening century has undoubtedly vitiated the arithmetic, but the fundamental principle remains valid, providing a salutary reminder, especially to those from the common law tradition, of the fallacy of regarding the will as the key vehicle of intergenerational wealth transfer. In fact, testamentary freedom was (and remains) rare in simpler societies; ${ }^{17}$

12 See eg Ely, "The Inheritance of Property" (1891) 153 North American Review 54 and Morton, "The Theory of Inheritance" (1894) 8 Harvard Law Review 161

13 T P T Plucknett, A Concise History of the Common Law, (5th ed, 1956) 711.

14 The following discussion proceeds on the basis that testamentary freedom is contrary to the family's interests. However, this ignores the fact that any assessment of how the right to will protects, or otherwise, the family can only be made in light of the alternative, the intestacy rules, at that moment in time. Historically, it is undoubtedly the case that there were times when testamentary freedom did actually constitute a protection for certain family members: see Miller, The Machinery of Succession (2nd ed, 1996) and Unger, "The Inheritance Act and the Family" (1943) 6 MLR 215. For the purposes of this article, however, which is concerned exclusively with the twentieth century, testamentary freedom is generally assumed to be capable of being used against the family's interests.

15 The movement away from blood relatives in favour of the deceased's spouse is one of the major trends in modern Succession Law - see generally, MA Glendon, The Transformation of Family Law (1989).

16 J Ely, "The Inheritance of Property" (1891) 153 North American Review 54 at 54.

17 See generally, Maine, Ancient Law (10th ed, 1927). Deus solus heredem facere potest, non homo (it is God, not man, who makes heirs) was a well-known maxim of the old Teutonic Law. Even in England, the home of the common law, the will emerged comparatively late in history. Land could not be willed until the enactment of the Statute of Wills 1540, and even then only to a limited extent (tenants by knight-service still had to leave at least one-third to descend under the inheritance law until the enactment of the Military Tenures Abolition Act 1660). 
religious codes such as the Sharia ${ }^{18}$ generally prescribed (and continue to prescribe) an intricate system of family inheritance, and to this day Scotland and virtually all continental jurisdictions, which also derive from Roman law, reserve a portion of a property-owner's estate for defined family members, the right to will being limited to that fraction which remains. ${ }^{19}$

In contrast, on colonisation in 1840 New Zealand had inherited the English common law $^{20}$ at the zenith of an "interval of unbridled testamentary licence", ${ }^{21}$ unrestricted testamentary freedom having been one of the fundamental tenets of the eighteenth century laissez-faire philosophy espoused by influential English writers such as John Locke and William Blackstone, during an era which has become known as the 'golden age of individualism'. Within decades, however, it had become evident that such unfettered testamentary freedom was a power which could be abused by the New Zealand husband or father at the expense of his wife and young children. ${ }^{22}$ Perhaps unsurprisingly it had been to the traditional fixed share that New Zealand's law reformers (many of whom had a Scottish

In Ireland the corresponding enactments were the Statute of Wills 1634 and the Tenures Abolition Act (Ir) 1662. Similarly, considerable restraints were placed upon the scope of wills of personalty until the fourteenth century - by virtue of the custom of legitim wives and children were guaranteed certain rights which could not be defeated by will. In effect no more than one half of the personal estate could be disposed of by will: subject to local variations a deceased who was survived by a wife and children was limited to disposing of no more than one-third of his personal estate, the so-called "dead's part". The wife was entitled to onethird and such of the children who had not been advanced in the deceased's lifetime were also entitled to one-third each (the bairn's part). Where the deceased was survived by a wife but no children, her and the dead's share increased to onehalf each. In Ireland these restrictions were not removed until the enactment of s10 of the Statute of Distributions 1695.

18 For further detail, see N J Coulson, Succession in the Muslim Family (1971) and Pearl and Menski, Muslim Family Law, chapter 11 (3rd ed, 1998).

19 Various names are given to such systems, eg Legitime (Spain); La Reserve (France); Pflichitteil (Germany); Jus Relicti and legitim (Scotland); Forced heirship (Louisiana). In the Republic of Ireland surviving spouses are protected in this manner by virtue of s 111 of the Succession Act 1965.

20 New Zealand was a ceded colony so English law did not apply automatically. The English Laws Act 1858 affirmed the reception of English Law retrospectively to 1840.

21 Per Lord Simon in Schaefer v Schuhmann (1972) 46 ALJR 82 at 90. The last vestiges of economic protection once afforded a widow had been swept away seven years previously by the Dower Act 1833 .

22 See in general Atherton, "New Zealand's Testator's Family Maintenance Act of 1900 - The Stouts, The Women's Movement and Political Compromise" (1990) 7 Otago LR 202. This article charts the background to the New Zealand legislation examining, amongst other factors, the role played by the Women's Movement. It has also been suggested that the need to restrict plenary testamentary freedom became an issue in New Zealand, and indeed in Australasia generally, long before it had in England because of the absence of the family settlement in the New World - see eg Lee, Manual of Queensland Succession Law (2nd ed, 1984). In England such family settlements, which generally defined with precision from birth the exact share of the patrimony which each family member was to receive, provided an effective fetter to the absolute testamentary freedom described above. They were, however, limited to the upper echelons of society. 
background) had first looked for a solution to this problem, but, perhaps just as unsurprisingly, such an undiscriminating intrusion into private property rights failed to secure majority support amongst the Liberal parliament-arians of the day. ${ }^{23}$

The ingenious political compromise ${ }^{24}$ between this mandatory fixed share system and absolute freedom of testation was a statutory provision based on discretion - a more flexible, targeted solution which accorded better with the prevailing Liberal ideology which had, by now, been forced to retreat significantly from its erstwhile uncompromising freedom of property ethic to endorse state intervention on moral grounds in order to protect the weaker members of society. ${ }^{25}$ Even then, however, acceptance was not immediate and the original drafting would have to be refined further to underscore that it was a moral basis which was sanctioning this interference with private property rights - this involved the insertion of a "disentitling provision" to clarify that a court could refuse to make an order in favour of any person whose "character or conduct" was undeserving of such help. ${ }^{26}$ On the third time of asking, however, the discretionary family protection mechanism gained the approval of a majority within the House of Representatives and the Testator's Family Maintenance Act, a short enactment of only twentytwo lines, received the Royal Assent on 9 October 1900. Its key provision was as follows:

"Should any person die, leaving a will, and without making therein adequate provision for the proper maintenance and support of his or her wife, husband, or children, the Court may at its discretion, on application by or on behalf of the said wife, husband, or children, order that such provision as to the said Court shall seem fit shall be made out of the estate of the said deceased person for such, wife, husband or children: Provided that the Court may attach such conditions to the order made as it shall think fit, or may refuse to make an order in favour of any person whose character or conduct is such as in the opinion of the Court to disentitle him or her to the benefit of an order under this section."

Such a mechanism was obviously in stark contrast to all existing fixed share approaches. Its claim to novelty was grounded in the innovatory

23 Sir Robert Stout introduced two fixed share Bills to the New Zealand Parliament, the Limitation of the Powers of Disposition by Will Bills 1896 and 1897. See generally Atherton, ibid.

24 The draftsmen responsible for this new formula were undoubtedly influenced by a legislative precedent of recent origin which also protected weaker members of society, s46 of the Native Land Court Act 1894. This provision empowered the Native Land Court to override wills of Maori testators in certain circumstances, a pragmatic solution to the common problem of forged Maori wills being presented in order to assert title to particular lands, in that it circumvented the need to prove fraud, always a difficult evidential hurdle. See further, Atherton op cit $\mathrm{n} 22$.

25 It was essentially the aftermath of the Industrial Revolution which exposed the complete inability of classical liberalism to protect the weaker members of society and thus precipitated this change. In England probably the most influential writer to articulate this new ideology was John Stuart Mill.

26 See Atherton, op cit $\mathrm{n} 22$. 
discretionary concept which it embodied - the legislature had not prescribed a uniform solution to be applied to every estate, but had merely empowered the Court to intervene on application by defined family members if, in the circumstances, it was necessary to vary the deceased's will because he had not adequately discharged his obligations to his family. Such a discretionary model could claim one very obvious advantage over its mandatory counterpart, namely the delivery of individualised justice. Unlike the mathematical fixed share, it was not forced to treat alike the "deserving and undeserving, rich and poor, old and young, strong and weak, burdened with small children and childless". ${ }^{27}$ Equally, however, it would not have needed a crystal ball to foresee that this immense flexibility could also quickly become its greatest weakness.

Legislation which empowers the judiciary to alter a deceased's testamentary disposition in favour of certain family members or other dependants may be framed with one of at least two different (and potentially conflicting) objectives in mind. Perhaps most obviously, it may be intended to serve a "support" function (that is, it is designed to provide for those in financial need, and possibly only for those whom the deceased had been required to support when he was alive). Alternatively, it may be intended to serve what could broadly be described as a "fair distribution" function (for example, it is designed to reward good conduct, or to provide recompense for past services, or to redress the deceased's lifetime failings, or, indeed, any combination of these). The former will involve a restrictive approach, connoting terms such as "maintenance", "income" and "dependence" and will be concerned exclusively with an applicant's economic need; the latter will involve an expansive approach, connoting terms such as "contribution", "capital" and "restitution" and will necessarily be concerned with matters beyond the economic status of an applicant.

With the Testator's Family Maintenance Act the New Zealand legislature granted the widest possible discretion to the Courts, but made no attempt to define the objectives which were to control its exercise, or to provide clear, ordered principles for guidance. Responsibility for determining what constituted "adequate provision for the proper maintenance and support" of an applicant was therefore abrogated entirely to the judiciary. A closer examination of the legislative background of this Act, however, would suggest that the absence of well-defined statutory guidelines was not an oversight, in that the tension between the "support" and "restitutive" functions of the proposed statute was already evident in the debates of the New Zealand Parliament which preceded its enactment. Although a minority of the House of Representatives favoured a broad approach which could take into account the claimant's station in life, rather than one limited to bare subsistence, (and the occasional Member even favoured a purely "dynastic" approach in which the primary objective was maintaining the patrimony within the family), the majority clearly saw the proposed legislation as an extension of the inter vivos support obligations contained in the Destitute Persons Act 1894, existing legislation which empowered the Court to order a living person to maintain certain destitute family members. Thus much of the debate pared down to a straightforward economic argument of "state" versus

27 Atkinson, Wills 679 (2nd ed, 1953), cited in Laufer, op cit n 9 at page 279. 
"estate", and the support given to the Measure before them by many Members of the House was entirely due to the fact that a testator could no longer foist his disinherited widow and dependent children on the public purse for support. Certainly, Robert McNab (although himself an advocate of the broader approach $)^{28}$ cast his last Bill firmly in terms of maintenance:

"[this Bill says] before you dispose of your property, first carry out your obligations; first see that you do not leave any person destitute; first see that any person who is at present dependant [sic] on you for his or her support and maintenance is not left on the state for support." 29

However, as has been seen, the wording which was finally enacted had a breadth and a generality such that it would be capable of being many different things to different people, including different judges. As one New Zealand commentator has observed:

"The Parliamentary Debates clearly reveal that there was no unanimous view as regards the nature and purpose of this legislation, but it was phrased sufficiently broadly to accommodate different as well as conflicting interpretations. It was the result of a political compromise and left the courts with the task of determining its scope" 30

It will be argued in the course of this paper that in the jurisdictions under consideration the Courts have generally struggled to determine the scope of the wide discretion granted to them by family protection statutes, with the result that, at times, the law in this area has been characterised by uncertainty and inconsistency, which should at least provoke the question "have the inherent weaknesses of the flexible restraint on testamentary freedom now started to outweigh its obvious benefits?" First, however, it is necessary to turn the clock back to Dannevirke, New Zealand on 11 March 1908, the date which witnessed the passing of a certain James Allardice Esq, and thus triggered the events which would culminate in the litigation which forms the basis of this paper. It is submitted that it is this decision, more than any other, which has been pivotal in setting the pattern for nearly a century of family protection cases throughout much of the English-speaking world.

\section{ALLARDICE V ALLARDICE}

In common with so many fellow testators who have also come to know posthumous fame through estate litigation in its various guises, the late James Allardice had enjoyed a colourful existence. His progression from a simple farmhand, whose only recognised talent was for breaking-in unruly horses, through storekeeping, to hotel ownership and the fortuitous acquisition of property at just the right time ensured that when he died in March 1908 he was able to leave behind a fortune of nearly $£ 30,000$,

28 The original wording of the Bill introduced by McNab was "due provision for maintenance and support", but once it had passed its Second Reading, he strategically changed the wording at Committee Stage to "proper" maintenance and support, a word which was to become pivotal in the later interpretation of the Act. See Peart, "Direction of the Family Protection Act 1955" [1994] NZRLR 193.

29 NZPD (1900) vol 111 cols 503 and 504.

30 Per N Peart, op cit $\mathrm{n} 28$ at 196. 
notwithstanding that his latter years were spent as "a drinking man of loose habits who must have squandered a good deal of his earnings." ${ }^{31}$ Affairs of the heart had proved no less colourful, and he also left behind a widow (Agnes), a former wife, (the first Mrs Allardice), and a total of thirteen children (seven by Agnes, the first six born out of wedlock, the remaining six by the first Mrs Allardice) ranging in stature from toddler to woman of nearly forty. For five years he had even succeeded in enjoying the company of the two woman simultaneously, but this arrangement was brought to an abrupt end in 1891 when the first Mrs Allardice discovered Agnes, ensconced in a house not far away at her husband's expense. From this time he lived with Agnes until his death, eventually marrying her in 1905 after a change in the law had enabled the first Mrs Allardice to obtain a divorce. To this large fortune and web of domestic relationships one must add the late $\mathrm{Mr}$ Allardice's will, which benefited only Agnes and her brood, and it should already be obvious that there existed all of the prerequisites for a long, expensive and potentially unsavoury family protection claim. In this regard it was not to disappoint, generating a mass of "very voluminous" evidence contained in thirty-seven affidavits, most of the which Chapman J, the judge at first instance, dismissed as "altogether irrelevant". ${ }^{32}$

In fact all but one of the deceased's six children by the first Mrs Allardice (three married daughters and two unmarried sons, all "thirty-somethings" by the time of their father's death ${ }^{33}$ applied for an award out of his estate under section 33 of the Family Protection Act 1908, the recently enacted consolidation of the earlier legislation, ${ }^{34} \mathrm{O}$ the basis that his will did not make "adequate provision" for their "proper maintenance". None of the five enjoyed a financial position which could have been described as "flourishing". The three daughters had all been "educated in as good a manner as could be secured in Dannevirke", primarily through the efforts and exertions of their mother. This had enabled them to secure husbands "of good character" and "of some capability, all of whom [were] able to work", but none of these men was comfortably off. One daughter, a Mrs Hawkins, was married to a journalist who at the time of the application had just embarked upon a small drapery business. Another, Mrs Hall, had been widowed but was now remarried to a man currently investing in a not too profitable sawmill venture. The third, Mrs Hazeldon, was the least well-off, being married to a clerk whose earnings the judge described as "precarious".

31 Per Chapman J at p 960.

32 Ibid.

33 The sixth, a daughter, had "married well" and made no claim. The first Mrs Allardice had no claim because she had been satisfactorily provided for in the divorce settlement.

34 The Testator's Family Maintenance Act 1900 had been speedily amended by the Testator's Family Maintenance Act 1906 in order to reverse the majority decision of the Court of Appeal in Plimmer v Plimmer [(1906) 9 NZGLR 10] that there was no jurisdiction to award a lump sum under the Act. The decision in Plimmer was delivered on 11 July 1906, the amending legislation was passed just over three months later on 19 October. This legislation plus a couple of minor amending statutes were then consolidated in the 1908 legislation. The key substantive provision of the 1908 Act remained the same as that in the 1900 Act, that is, had the deceased made "adequate provision for the proper maintenance and suppport" of the applicant? 
Her brothers appeared to be in a similarly precarious financial situation. They continued to live with their mother on her small thirty acre freehold farm while working as labourers on this land. One had been trained as a saddler at his father's expense, previously embarking upon an unsuccessful business venture in this field on which his father lost the $£ 250$ he had put up as a guarantee; the other possessed no particular skill, save that he appeared to have inherited his father's flair for horse-breaking. In short, they were two able-bodied men, whose only property was their personal effects, but neither of whom, to quote Chapman J, seemed to "exhibit any ambition to rise above their present position." The learned judge summed up the problem before him as follows:

"What I really have to consider in this case is whether the Act has any application whatever to able-bodied sons who are capable of supporting themselves in the condition in which they have hitherto lived and who have done so ever since they came to man's estate, or to married daughters who never have been dependent on their father since they were married and whose husbands are capable of supporting them in the future as they have supported them in the past". ${ }^{35}$

Chapman $\mathbf{J}$ duly answered both of his questions in the negative, refusing to make an award in favour of any of the applicants. It had been submitted on behalf of the five children that the deceased had failed to make proper provision for them - more specifically, that the deceased should have attempted to redress the fact that he had failed to educate his sons in a manner more in keeping with his wealth, and that in the case of his daughters he had failed to supplement their slender means.

In rejecting all of the applications, Chapman $\mathrm{J}$ emphasised that he was taking "his guidance exclusively from the statute". ${ }^{36}$ It was evident that the learned judge had a certain sympathy for the three female applicants, but felt that he was not empowered to rectify the injustice which he believed had been done to them - he could have no concern, he stated, with what their "father ought in justice have done beyond the standard [which he] derived from the statute." This "standard" he clearly defined in terms of the relief of destitution, and the three women, while married to men on low wages, could not properly be described as being "in want". ${ }^{37}$ Significantly, also, they, like their brothers, would have no legal claim to be supported by their father if he were still alive since they were outside the scope of the Destitute Persons Act.

The applicants appealed to the New Zealand Court of Appeal on the ground that the trial judge had exercised his judicial discretion on erroneous principles in that he had failed to put due weight on the requirement that the maintenance be "proper". More specifically, their counsel submitted, Chapman $\mathbf{J}$ had not given consideration to the relatively large value of the estate and to the natural obligation which a parent has to make provision for the "proper maintenance" of his children. The Court of Appeal (Stout CJ,

35 At p 964.
36 At p 964.
37 At p 966. 
Cooper, Edwards and Williams JJ) unanimously affirmed the judge at first instance with reference to the two able-bodied sons, but reversed the decision in relation to the three married daughters, awarding Mrs Hazeldon $£ 60$ per annum and the others each $£ 40$ per annum.

Sir Robert Stout, now the Chief Justice, but who during his time in the House of Representatives in the 1890's had been the Member responsible for introducing the two aborted fixed share Bills, delivered the leading judgment, summarising the principles which had been established in the cases decided in the first decade of family protection as follows:

" 1 , That the Act is something more than a statute to extend the provisions of the Destitute Persons Act; 2, that the Act is not a statute to empower the Court to make a new will for the testator; 3, that the Act allows the Court to alter a testator's disposition of his property only so far as it is necessary to provide for the proper maintenance and support of 'wife, husband or children' where adequate provision has not been made for their proper maintenance and support by the will of the testator; 4 , that - in the case of a widow, at all events, if not in the case of a widower - the Court will make more ample provision than in the case of children, if the children are physically and mentally able to maintain and support themselves." 38

Both Sir Robert and Cooper $\mathbf{J}$ respectively gave examples in the course of their judgments of the type of matters which the Court might take into account when exercising its discretion:

"The Act has laid down no rule, and has left the decision in every case to the discretion of the Court. What, then, has the Court to consider: Firstly, I think, the means of the children. 'Support' it has been held - at all events, in the case of a widow - does not mean merely having a supply of food and clothing. It means, it has been held, such kind of maintenance as the widow during the life of her husband has been accustomed to. The matter that should be considered, both as to widow and children, is how she or they have been maintained in the past. A child, for example, that has been living on a father's bounty could not be expected to begin the battle of life without means. A child, however, who had maintained her or himself, and had perhaps accumulated means, might well be expected to be able to fight the battle of life without any extraneous aid. But even in such a case, if the fight is a great struggle, and some aid might help and the means of the testator were great, the Court might, in my opinion, properly give aid. The whole circumstances have to be considered. Even in many cases where the Court comes to a decision that the will is most unjust from a moral point of

38 At p 969. 
view, that is not enough to make the Court alter the testator's disposition of his property." ${ }^{39}$ and

"In my opinion it is impossible to lay down, except in very elastic terms, any general rule in such a case, for many factors have to be considered. The condition of life of the testator and the children, the sex, age and health of the children, whether, if daughters, they are married, or, if sons, they are of sufficient health and strength to earn a reasonable maintenance for themselves or those dependent upon them. . . But. . . I repeat that we have no power to recast the testator's will or to redress inequalities or fancied injustice. . .".40

Notwithstanding that both men were careful to draw attention to the fact that they were not empowered to rewrite wills found "unjust from a moral point of view", it is evident that their approach to the exercise of discretion under the 1908 Act was much more subjective than that which had been adopted by Chapman J. The destitution of the applicant, seemingly a sine qua non for judicial intervention at first instance, was now one of a variety of matters to be considered relevant, including the wealth of the deceased, the means of the children, and their sex, age, health and marital status. It was Edwards J, however, who crystallised this thinking in the famous words which appeared earlier in this paper:

"It is the duty of the Court, so far as possible, to place itself in all respects in the position of the testator, and to consider whether or not, having regard to all existing facts and surrounding circumstances, the testator has been guilty of a manifest breach of that moral duty which a just, but not a loving, husband or father owes towards his wife or towards his children, as the case may be. If the court finds that the testator has been plainly guilty of a breach of such a moral duty, then it is the duty of the Court to make such an order as appears to be sufficient, but no more than sufficient, to repair it."

When their Honours applied these principles to the facts before them they were unanimous that no award should be made in favour of either son, who:

"If they had any push they should, considering their age, have ere this done something for themselves, and to settle money on them now might destroy their energy and weaken their desire to exert themselves". ${ }^{42}$

In the case of the daughters, however, annuities were awarded, the main factor influencing the Court being the likelihood that in the future their husbands might no longer be able to support them.

The plaintiffs appealed to the Privy Council which approved the decision ${ }^{43}$ and general approach of the New Zealand Court of Appeal, but in a "cursory

39 Per Stout CJ at 969-970.

40 Per Cooper J at 974-975.

41 At $\mathrm{p} 972$

42 Per Stout CJ at 971.

43 [1911] AC 730. 
manner", ${ }^{44}$ with a good part of the short opinion which was delivered by Lord Robson on behalf of the Board given over to observations about the inappropriateness of a body in London interfering with the exercise of discretion by "local courts [which] are well acquainted with all the local conditions as to employment, standard of living and other matters necessary to be borne in mind." 45

It should already be evident that it is not the actual decision reached by the New Zealand Court of Appeal on the facts before it which justified the accolade made earlier that Allardice is one of the most pivotal family protection cases, for on that level, notwithstanding the awards made in favour of the daughters, it was a relatively narrow interpretation of the relevant statutory provision. The outcome, two young men sent back emptyhanded to their mother's farm, with judicial exhortations about the virtues of self-reliance probably still ringing in their ears, was completely in line with the existing jurisprudence on claims from able-bodied adult children:

"Adult children capable of maintaining themselves may come within the statute of 1900 . As to this, I express no opinion. It would, however, I think require a very strong case to justify the Court in making an order under that statute in favour of such a child overriding the will of the testator." 46

Rather, the main significance of Allardice is found in the gate which Edwards $\mathrm{J}$ had firmly opened with his enunciation of the "breach of moral duty" principle, the practical outworkings of which invited the Court to consider a wide range of factors, the ethical as well as the economic. Although the judiciary would tend to tread very warily through this gate for some years, they would eventually succeed in exploring the full extent of the terrain which lay beyond, gradually introducing more and more matters as relevant to the assessment of a testator's moral duty. It would only be then that the magnitude of the inroads which the decision in Allardice had made to the concept of testamentary freedom would become apparent.

Meanwhile, in 1938 the Privy Council enjoyed a further opportunity to consider a Commonwealth family protection case, Bosch $\mathrm{v}$ Perpetual Trustee $\mathrm{Co}^{47}$ an appeal from New South Wales concerning an application under the Testator's Family Maintenance and Guardianship of Infants Act 1916. ${ }^{48}$ Their Lordships expressly affirmed the "moral duty" test from Allardice, but reformulated it in slightly different terms:

"in every case the Court must place itself in the position of the testator and consider what he ought to have done in all the

44 Tyler's Family Provision (3rd ed, RD Oughton, 1997) at $\mathrm{p}$ 8. The matter was argued for less than a full day since part of the day was spent hearing Samaradiadiwakara v De Sarum [1911] AC 753.

45 Per Lord Robson at 734.

46 Per Edwards J in Rush v Rush (1901) 20 NZLR 249. Rush was the first reported case on the 1900 Act.

47 [1938] AC 463.

48 The key provision of this legislation was s 3 which empowered the testator's spouse and children to apply for an award out of his estate if they had been left "without adequate provision for their proper maintenance, education or advancement in life as the case may be." 
circumstances of the case, treating the testator for that purpose as a wise and just, rather than a fond or foolish, husband or father." 49

The judicious husband and father, now also credited with the virtue of wisdom, ${ }^{50}$ and already accepted in Canada, ${ }^{51}$ as well as Australasia, had, in the words of one senior member of the New South Wales Bar, been "virtually endowed with perpetual succession". ${ }^{52}$ And so the "judicial gloss" which had first emanated from the New Zealand Court of Appeal in Re Allardice, would continue to dominate Commonwealth family protection law, such that, some forty years later, one New Zealand judge would observe:

"[t]he concept of moral duty, what the wise and just testator would have done, is elementary in the administration of the Family Protection Act in New Zealand. It is too deeply embedded to be open to judicial reconsideration now." 53

We turn next to chart the development of this "moral duty" approach since its inception in 1910, focusing, in particular, on how "what the wise and just testator ought to have done" has altered with the passage of time. For this we leave behind the wise and just husband and concentrate exclusively on how the Australasian and Canadian judiciary have defined the testamentary obligations owed by a just and wise father towards his grown-up able-bodied offspring. In one respect, however, it is impossible to leave behind the judicious husband completely. As with any "cake-cutting" exercise, family protection awards made to one particular category of applicant can only be analysed meaningfully in the context of competing claims from other classes of applicant. However, Allardice confirmed, and later jurisprudence has entrenched, that a husband's responsibilities to his wife and infant children are paramount. Many cases which culminate in litigation will not therefore involve adult children competing with the deceased's spouse (especially if that person is also the applicant's other parent) or infant children - but with their equally mature siblings, remoter family members, or charities.

The adult child (an eligible claimant under many Commonwealth statutes) has been highlighted because it is he or she who represents the "sharp end" 54 of the family protection jurisdiction - what Edwards $\mathrm{J}$ in Allardice described as "the extreme case". ${ }^{55}$ It is thus in relation to this category of applicant that one might expect any misgivings about the workability of the "moral duty" approach to be most readily confirmed or dismissed. This article is not

49 Per Lord Romer at p 474.

50 The notion of wisdom was first introduced in Allen $\mathrm{v}$ Manchester [1922] NZLR, a case which was expressly affirmed by the Privy Council in Bosch.

51 The Supreme Court of Canada endorsed the moral duty test in Walker v McDermott [1931] DLR 662.

52 C McLelland, "Fifty Years of Equity in New South Wales- A Short Survey" (1951) 25 Australian Law Journal 344 at 344.

53 Per Cook J in $\operatorname{Re~Z~[1979]~} 2$ NZLR 495 at 506.

54 Green, "The Englishwoman's Castle - Inheritance and Private Property Today" (1988) 51 MLR 187 at 196

55 At p 973. Edwards J was referring to an adult son, but now, as shall be seen, this could be applied equally to an adult able-bodied daughter. 
directly concerned with the Irish judiciary's application of the statutory "breach of moral duty" test found in section 117 of the Succession Act 1965, nor with the treatment of adult children in the rather different family protection jurisdictions of England and Northern Ireland. An analysis of the exercise of judicial discretion in these jurisdictions would form the basis for separate papers. Yet the experience of the Commonwealth courts is clearly not without relevance to the operation of the flexible restraint on testamentary freedom closer to home. While the inheritance law of any given society will be shaped and influenced by its distinctive cultural requirements, certain problems are common to all succession regimes. The place which adult children should occupy within the framework surely falls within this latter category.

\section{NINETY YEARS OF MORAL DUTY OF A WISE AND JUST FATHER}

\section{Introduction}

Restraints of space preclude a systematic survey of the case law from each of the Commonwealth jurisdictions which have granted locus standi to adult children and measured the testator's conduct in such cases against the standard of a "wise and just father". The approach adopted below, therefore, has been to focus primarily on the New Zealand jurisprudence, in that the principles first developed there have then often been endorsed and applied by other Commonwealth jurisdictions. In order to illustrate both the huge range of factors which the courts have come to consider as relevant to the testator's moral duty and the major trends in the decades since Edward J's judgment in Allardice was handed down, several Canadian and Australian cases have also been included. Little attempt has been made, however, to deal with the jurisdictions separately - it is generally the case that Commonwealth countries "have drawn freely on one another's decisions" 56 and differences of interpretation between minor variations of wording have been discouraged:

"The legislation of the various [Australian] States is grounded on the same policy and found its source in New Zealand.

Refined distinctions between the Acts are to be avoided." ${ }^{57}$

\section{The First Half Century}

Many cases have expressed the sentiment that what constitutes a "breach of moral duty" will change from period to period because a family protection statute "is a living piece of legislation", the application of which "must be governed by the climate of the time." 58 Change during the first half of the century, however, was relatively slow. Rather, this period was marked by a number of gradual developments, minor in themselves, but which built on

56 Laufer, op cit $\mathrm{n} 9$ at 288. Laufer also notes that this characteristic has not been shared by the English judiciary. However, the English (and Northern Ireland) legislation is less broadly drawn. The implications of the issues discussed in this paper for England, Wales and Northern Ireland are discussed briefly below.

57 Per Dixon CJ in Coates v National Trustees Executors and Agency Co Ltd CLR 494 at 507.

58 Per McCarthy P in Re Wilson [1973] 2 NZLR 359 at 362. 
the foundations laid in Allardice and paved the way for the broader interpretation of the statutory provisions which would not properly gain momentum until the latter half of the twentieth century.

As noted earlier, the first decisions of the New Zealand Courts on the Testator's Family Maintenance Act were characterised by a very narrow interpretation of the words "adequate provision" for "proper maintenance", one which cast the function of this legislation firmly in terms of support for those in need, and then only for those whom the deceased had a lifetime obligation to support. Thus the link with the Destitute Persons Act which had figured prominently in the Parliamentary debates continued to provide the predominant thrust of the pre-Allardice judgments, most of which (including those delivered by Edwards J and Stout CJ) limited the Testator's Family Maintenance Act in this manner. On occasions the amount to which an applicant would have been entitled under the Destitute Persons legislation was also used to determine the quantum of the award to be made under the Testator's Family Maintenance Act. ${ }^{59}$

It was emphasised earlier that Allardice's full impact cannot be assessed in the short-term. It would be doing the decision an injustice, however, not to recognise that it made an immediate contribution to the interpretation of its own "moral duty" test, beyond the basic principle that adult daughters married to men of poor means were owed obligations which were more extensive than those owed to their unmarried brothers. It also provided clear appellate authority that family protection was not simply an extension of the Destitute Persons Act. Hence, within just ten years of the enactment of the Testator's Family Maintenance Act, an Act which had secured its passage through the New Zealand Parliament by virtue of the savings it was promising the welfare purse, there had been unequivocal rejection of the idea that family protection was intended to serve only a support function in its narrowest sense.

Notwithstanding this, however, or the dicta in Allardice that the size of a deceased's estate and certain other matters may be relevant to the assessment of any moral duty, the emphasis remained for some years on the economic need of the applicant, albeit no longer need in the narrow context of the Destitute Persons Act. It was twelve years before there was any real evidence of a more liberal approach in which courts were prepared to attach significant weight to the means of the testator. Then in Allen v Manchester, ${ }^{60}$ in what has been described as a "classic formulation", Salmond J divided family protection cases into two broad categories. First, those where:

"owing to the smallness of the estate and to the nature of the testamentary dispositions, the applicant is competing with other persons who also have a moral claim upon the testator ${ }^{61}$. .. [and secondly, those] in which owing to the largeness of the estate or the nature of the testamentary dispositions, the applicant for relief is complaining not of the unjust distribution of an inadequate fund among dependants all of whom had a

59 See eg, Re Rush (1901) 20 NZLR 249 at 254.

60 [1922] 41 NZLR 218.

61 Ibid at 221 
moral claim upon the testator, but of the failure of the testator to make out of the abundance of his resources a provision sufficient for the proper maintenance of the claimant."62

This latter type concerned:

"the more difficult function of determining the absolute scope and limit of the moral duty of a wealthy husband or father to make testamentary provision for the maintenance of his widow and children." 63

Allardice, opined Salmond J, fell within the first category and as such was not a decision that a testator owed no moral duty to an adult son capable of earning his own living, nor that the moral duty towards an adult daughter was limited to provision of an annuity. Rather, that particular case was:

"merely a decision as to the just and proper method of distributing between the various claimants an income not adequate to meet in full the moral claims of all of them"

In Allen v Manchester itself the court was not required to make a decision about adult children, but Salmond J's dicta, particularly his reference to the "absolute scope and limit" of the moral duty of a wealthy father towards his children, undoubtedly pointed towards significantly more substantial provision for adult offspring than that previously recognised by the courts. Within two years, in Welsh $\mathrm{v}$ Mulcock, ${ }^{64}$ Salmond $\mathrm{J}$ enjoyed a further opportunity to provide more guidance on the extent of this duty. Having intervened during the submissions to ask counsel whether the word "adequate" should be considered "ethically or economically", the learned judge made it clear during his judgment that he preferred the former approach. On a narrower level, the case is authority for the principle that the true measure of a testator's moral obligation is not necessarily found in the standard of maintenance and way of life to which the family was accustomed in his lifetime, so that he

"cannot, by failing in his duty to [his wife and children] while alive, reduce the standard of his testamentary obligations towards them on death." 65

However, it was Bosch v Perpetual Trustees ${ }^{66}$ (an appeal from New South Wales in which, it will be recalled, the Privy Council expressly affirmed the Allardice moral duty approach), which heralded the most significant broadening of approach. In a clear departure from the earlier case law, which tended to focus on the meaning of the term "adequate provision", the Board concentrated primarily on the interpretation of the words "proper maintenance". While a small sum might be sufficient for the "adequate" maintenance of a child, Lord Romer pointed out, ${ }^{67}$ it might not, having

62 Ibid at 222

63 Ibid at 222. Author's emphasis.

64 [1924] NZLR 673.

65 Ibid At 686.

66 [1938] AC 463.

67 Ibid at 476. In Bosch the Privy Council allowed the costs of an Oxbridge education to come within the concept of "maintenance, education and 
regard to that child's station in life or the size of the estate, be sufficient for his "proper" maintenance. In particular, his Lordship continued, where the estate was large, the court would be justified in making provision to meet contingencies which might have been disregarded had the estate been small.

Bosch thus established conclusively that an applicant's economic need was only one factor in what constituted "proper" maintenance for him or her, and thus only one factor relevant to the assessment of the deceased's moral duty to that person. Not only therefore was the wording of the various family protection jurisdictions sufficiently general to accommodate the tensions between the support and contribution functions of family protection, it could be construed as reflecting those very tensions in its drafting. As Greeson J would later observe in Re Strawbridge, Telfer v Strawbridge: ${ }^{68}$

"[i]t would seem that 'adequate' has regard rather to the necessities of the applicant but that what is 'proper' has regard to all the attendant circumstances."

In practice, however, the courts generally remained reluctant to make full use of the approach developed in Bosch ${ }^{69}$ and the wise and just father of the middle years of the century could generally prepare to leave this world content that only children unable to support themselves because of their age, poor health or other limited circumstances could successfully challenge his own distribution of his property. By now there had developed a body of case law based on relatively well-defined judicial principles, so that notwithstanding the element of uncertainty which is inherent in any discretionary system, it was generally possible to predict with considerable confidence how cases would be decided. Writing in 1941 the editor of the Australian Law Journal was able to commend

"[the] Dominion Equity Judges [for giving] the jurisdiction a settled body of practice which made it possible to advise

clients with accuracy as to claims under the legislation." 70

Similarly, Joseph Laufer, having reviewed authorities from Australasia and the five Canadian Provinces which had by 1955 adopted family protection mechanisms, concluded that:

"[t]he Courts have responded to [the] broad delegation of control over private property rights with characteristic selfrestraint. They have emphasised the limitations on their functions rather than stressed their powers." 71

The flexible restraint on testamentary freedom had been widely acknowledged as a success and many jurisdictions were starting the process of replacing, or amending, the original legislation by provisions which generally:

advancement" found in s 3 of the Testator's Family Maintenance and Guardianship of Infants Act 1916.

68 [1952] GLR 442 at 445 .

69 See further Laufer, op cit n 9; Peart, op cit n 28 and M Brown, "The Dependants Relief Act" (1940) 18 Canadian Bar Review 261 at 264.

70 (1941) 15 Australian Law Journal at p 198.

71 Laufer, op cit $\mathrm{n} 9$ at $\mathrm{p} 289$ 
"tended. . . to discard limitations, both substantive and procedural, by which anxious legislatures had originally sought to contain both the scope of the statutes and, especially, the sweep of judicial discretion." 72

For instance, in New Zealand the Family Protection Act 1908 was repealed and replaced by the Family Protection Act $1955^{73}$ which widened the class of eligible applicant. However, the key provision remained substantially unchanged; had the testator provided "adequate" provision for the "proper" maintenance of the applicant. Breaches of moral duty by the just and wise father, although not incorporated in any of these statutes, remained the standard against which the court would determine whether or not this had been achieved. While, however, these statutory changes were not directly related to the scope of discretion, their expansive nature may have acted as a catalyst for a similarly expansive approach to the interpretation of the legislation, for it was around this time that there was a perceptible change - a change which was especially evident in relation to adult child claimants.

\section{Mid-Century to Date}

The certainty, predictability and consistency which were widely accepted concerning the first generation or so of family protection cases, even at the "sharp" end of its jurisdiction, would appear to be no longer a feature of the modern Commonwealth jurisprudence in the area. Thus while a future member of the New South Wales Bench could confidently proclaim in 1951 that:

"no judge has ever worn the mantle [of just and wise fathers] with the abandon one would expect of a Medieval Chancellor suitably modernised. . ." 74

one wonders if the proverbial "Chancellor's foot" is not again very much in evidence:

"Emphasising the testator's 'moral duty' leads to a judicial free-for-all. Alternatively one might say, in a free adaptation of the words of John Selden, that with such judicial power a testator's 'moral duty' will vary according to the conscience of each individual judge, and as that is longer or narrower, so is the duty." 75

Moreover, this appears to have been the experience, to a greater or lesser extent, of every jurisdiction in which the "moral duty" approach has been

72 Ibid at $\mathrm{p} 284$.

73 The legislation from the other jurisdictions was noted above at $\mathrm{n} 2$.

74 C McLelland, op cit $\mathrm{n} 52$ at 344.

75 Oosterholf, "Succession Law in the Antipodes: Proposals for Reform in New Zealand" (1997) $16 E \&$ \&J 230 at 236. The famous words of John Selden referred to are: "Equity is a roguish thing. For law we have a measure ... Equity is according the the conscience of him that is Chancellor, and as that is longer or narrowe, so is equity. Tis all as if they should make the standard for the measure a Chancellor's foot." 
embraced and, as might be expected, the difficulties have been particularly acute in relation to able-bodied adult children. ${ }^{76}$

In British Columbia, one judge has observed in relation to such claims under the Wills Variation Act 1979 and its predecessor:

"The law developed in these cases is in a state of disarray such that it is all but impossible to predict with any confidence what result will flow from any given set of facts and unduly difficult to decide what the result should be. . .",77

and a leading academic has despaired that the courts of that Province appear to be "dispensing palm tree justice,"78 likening the Wills Variation Act to "a ship adrift at sea without an accurate compass or dependable rudder". ${ }^{79}$ Similarly, in Manitoba, the Law Reform Commission, ${ }^{80}$ having cited numerous examples of successful claims by able-bodied adult children ${ }^{81}$ who had not been dependent on the testator for support, criticised the "uncertainty and inconvenience" of the moral duty approach to the Testator's Family Maintenance Act, a further effect of which was to transform family protection

"in substance. . . from a mere limitation on testamentary power into an emerging principle that children are entitled to a share of their parent's capital estate." 82

Even in New Zealand, the country which gave the world both the discretionary-model family protection mechanism and the juristic father who has been largely responsible for shaping its course, widespread dissatisfaction, particularly with the state of the authorities on adult children, has led the New Zealand Law Commission to undertake a fullscale review of all existing succession structures. ${ }^{83}$ A survey commissioned as part of this review, ${ }^{84}$ by New Zealand academic Nicola Peart involving 235 cases from 1984-1995 where children claimed against their parent's estates under the Family Protection Act 1955, suggested that as many as $91.5 \%$ of children's

76 There have been other controversial categories of eligible applicant in a number of jurisdictions - eg those who claim by virtue of de facto dependency and cohabitants. However, it is probably a fair comment that they have not generated the same difficulties as adult children. In any event they raise somewhat different issues, and are outside the scope of this paper.

77 Per Esson JA in Price v Lypchuk Estate 26 ETR 259 at 276.

78 G Bale, "Palm Tree Justice and Testator's Family Maintenance - The Confusing Saga and Uncertainty in BC Courts" 26 ETR 295 at 313

79 Ibid at 315.

80 Manitoba Law Reform Commission Reports, Report on Testator's Family Maintenance Act (1985). Following the recommendation of this report the Testator's Family Maintenance Act 1946 was replaced by the Dependants Relief Act 1989-90 under which applications must be grounded in economic need.

81 Eg Re Bartel Estate (1982) 16 Man R (2d) 29 (QB); Dutka v Dutka's Estate (1980) 7 Man R (2d) 211 (QB); Menrad v Blowers (1982) 16 Man R (2d) 288.

82 Op cit $\mathrm{n} 80$ at $\mathrm{p} 26$.

83 In August 1996 the Commission published a detailed technical paper - Succession Law: Testamentary Claims - A Discussion Paper (NZLC PP 24, 1996). This was followed by a Report in August 1997 which included a draft Succession (Adjustment) Act. It has not yet been enacted.

84 Peart (1995) BFLJ 224. 
claims are successful when contested. In more than a quarter of these the children had not been dependent on their deceased parent (the just and wise father having been suitably modernised by the 1990's). As Peart has concluded:

"[a] substantial number of adult children apply under the Family Protection Act every year alleging a breach of moral duty on the part of their deceased parent and they are almost always successful ... The testatmentary freedom which exists now is but a hollow image of its former self, [and]. . . exists in reality only for those without families." 85

In the course of the last forty years the Commonwealth courts have generally overcome their initial reluctance to wear the mantles of just and wise fathers with "abandon" (the suggestion by one Canadian commentator, that this early reluctance was rooted in the traditional common law separation of law and morals, would seem to have much merit $)^{86}$ to move to a position where, although the economic need of the applicant remained the first consideration, other ethical issues were then introduced and taken into account, through to one in which an applicant may succeed even if he or she is in very comfortable financial circumstances:

"The 'need' of an applicant, or rather his or her needs - the plural form is I think preferable - cannot be considered in vacuo. What has to be assessed are the merits of the claim having regard to the applicant's circumstances as at the date of the death of the testator; relations between the testator and the applicant in the past; and the extent of his estate and the strength of other claims". ${ }^{87}$

The above quote came from Re Harrison, a case in which it was held that a testator could owe a moral obligation to an adult daughter even though she was not in necessitous circumstances; indeed, even an adult in a reasonably strong financial position could expect to receive something under the will in view of the size of the testator's estate. In Harrison itself the court was clearly influenced by the source of the deceased's money, much of which he had inherited from his own father and an uncle - it was "grandfather's money". The testator's widow was not the mother of the applicant, and it was thought to be unlikely that she would make any provision for the applicant in her will. In fact, it appears that applicants who are the children of a first marriage when the testator has remarried now invariably receive something under the family protection legislation (even against the widow) in both New Zealand and Australia ${ }^{88}$ - a clear example of the statutes serving elements of both the "fair distribution", and "dynastic" functions, but certainly not a support function.

Another situation in which adult children appear to succeed, virtually as of right, to a share of the estate, at least in Australia, is where the testator was

85 Peart, op cit at $\mathrm{n} 28$ at 209.

86 M Brown, op cit at $\mathrm{n} 69$ above at 264

87 Re Harrison [1962] NZLR 6 per Gresson J.

88 See generally Peart, op cit $\mathrm{n} 28$ and Atherton and Vines, Australian Succession Law, Commentary and Materials (Australia, 1996) 689-705. 
very wealthy. ${ }^{89}$ Even in relation to more modest estates, however, the likelihood of securing an award is much better than it would have been in past decades. The principle of self-reliance which pervaded the earlier jurisprudence concerning able-bodied applicants, particularly males, has generally given way to a more sympathetic approach. If this change in judicial attitude can be marked by a single turning-point, it is probably the Australian decision of Hughes v National Trustees Executors and Agency Co of Australasia Ltd, ${ }^{90}$ in which Gibbs J endorsed intervention in favour of an adult son who, notwithstanding his physical well-being, simply found it more difficult than most to deal with the vicissitudes of life's rich tapestry:

"I do not think that the Legislature intended that provision under the Act should be given to those that are efficient and successful rather than to those who are not. A just father's moral duty is to assist the lame ducks among his offspring, provided that they be not morally or otherwise undeserving."91

Indeed, often the modern basis of successful child applications is no more than the fact that the parent's estate has a symbolic value. As Peart has observed of New Zealand claims:

"[the estate] has a symbolic value. . . in that it is the remaining tangible link to the parent. Complete or partial exclusion from the estate may then be seen as exclusion from the family bond. The estate becomes the symbol of the parent-child relationship, and it is this, rather than financial need, which appears to motivate many adult children to claim against the estate of their deceased parent." 92

In support of her submission that New Zealand is moving "towards a concept of family property," 93 Peart charts a shift from "support stage" through "contribution stage" to "relationship stage", citing as evidence of the final stage a number of adult applicants who appear to have benefited under the Family Protection Act simply by virtue of the genealogical link with their parents:

"[children's] needs are not in the strict sense for maintenance or monetary provision but are rather to recognise the family connection and the relationship, the familial demand." 94

This more expansive exercise of discretion has been allied to a correspondingly more generous interpretation of the "disentitling provisions"; for example, in Re Mercer ${ }^{95}$ Roper J noted that conduct which may have been sufficient to disentitle an applicant in earlier times would not necessarily do so in today's climate and duly made an award to a rebellious

99 Atherton and Vines, ibid at 702.

90 (1979) 143 CLR 134.

91 Ibid at 139

92 N Peart, op cit $\mathrm{n} 28$ at 207.

93 Peart, "Towards a Concept of Family Property in New Zealand", International Journal of Law, Policy and the Family 10 (1996) 105.

94 Per Greig J in Re Adams, HC Wanganui, A34/84, 1 April 1986 cited in Peart, op cit at $\mathrm{n} 28$ at 207.

95 [1977] 1 NZLR 469. 
twenty-four year old son of the testator, on the basis that his father "should have recognised that his son's make-up was such that he would need some support." It would seem, therefore, that the judiciary are slow to judge children "morally or otherwise undeserving", and that the judicious parent is now "not only wise and just but also contrite and forgiving." 96

In short, the term "moral duty", first clearly enunciated in Allardice, has come to encompass a host of different factors, including: the age, marital status, health and earning capacity of the applicant; his or her past standard of living - and future prospects; the poor conduct of the testator towards the applicant; past services provided to the deceased by the applicant ; and even simply the existence of a family link between the applicant and the deceased. The result is that both this duty, and the consequent invasion which it has made on testamentary freedom, are far more extensive than anything envisaged by either the framers of family protection legislation or the members of the New Zealand Court of Appeal who delivered the Allardice judgment. Successful claims by able-bodied adult children who were not in need, even in the broadest sense of the word, appear to abound in every Commonwealth jurisdiction in which the courts have perceived their function in relation to family protection as rectifying the moral failings of a wise and just father. Illustrations can readily be found of awards made to adult children which serve a support function by making provision for those in clear economic need; of others which demonstrate a restitutive or equitable distribution function, by rewarding the child's good conduct or compensating for the testator's bad conduct; and of yet others which further, if not a dynastic, at least a "family property" function, by symbolising the family bonds which ought to exist in a household. It is the household, it seems, of "the paragon of wisdom and justice who is seldom encountered on the Clapham omnibus"; 97 a household which now includes the ne'er do well, the lame duck and even the black sheep.

\section{INTO A NEW CENTURY - WHAT FUTURE FOR THE WISE AND JUST FATHER?}

Allardice v Allardice was the first case to analyse New Zealand's still young family protection jurisdiction in terms of the moral duties owed by a just testator to his wife and children. Since then, notwithstanding occasional attempts by certain members of the judiciary to remind their colleagues that although

"[the notion of the moral duty owed by a wise and just testator] may be a helpful gloss in many cases, . . . when a critical question of meaning arises, the question must be answered by reference to the text, and not by reference to the gloss. It is the text, and not the gloss, that we are called upon to interpret. . . ".98

96 J L Caldwell, "Family Protection Act 1955 - Moral Duty and Adult Children" (1982) New Zealand Law Journal 215 at 218.

${ }^{97}$ Re Bartel Estate (1982) 16 Man R 29 at 32, per Scollin J.

98 Per Fullagar J dissenting in Coates v National Trustees Executors and Agency (1956) 95 CLR 494 at 523. See also Jordan CJ in Re FJ McNamara dec'd (1938) WN (NSW) 180 - the gloss "likely to obscure rather than to clarify the 
Edwards J's words which constitute this "gloss" have become the locus classicus in the area, repeated

"every year since $1910 \ldots$ in every Court in [New Zealand], and never with any qualification or question. The principle which they expound has again and again been approved by our greatest Judges. . ." 99

- a remark which is equally valid for the Australasian and a number of the Canadian Courts. Few would dispute that Cooke $\mathrm{J}$ was correct in his assessment that this judge-made creation has become "too deeply embedded"100 in family protection jurisprudence in these countries to be removed other than by statutory intervention.

Yet it would appear that the experience of those Australasian and Canadian courts which have perceived the primary purpose of family protection statutes as enforcing the moral duties of the deceased has not been an unmitigated success, at least in relation to adult child claimants. On the contrary, the evidence from these jurisdictions suggests that the law in this area has been racked with uncertainty and inconsistency, to such a degree that it has become virtually impossible for anyone with a legitimate interest to know the exact nature of either their obligations or their rights. Meanwhile, this level of unpredictability provides a very fertile breeding ground for that inevitable contra-indication of any discretionary system - the frivolous claim. It might be impossible to eliminate this type of action completely, but amid such confusion even the most unworthy of applicants are endowed with that "enhanced nuisance value" 101 which tends to make any settlement more attractive to a beneficiary under a will than the risk of litigation.

It would, of course, be doing an injustice to lay responsibility for this state of affairs entirely on the shoulders of the judiciary. No doubt when Edwards J expounded his now familiar words it was a bona fide attempt to fill the very conspicuous void left by the legislature. As has been noted, there was a certain ambiguity about the objectives of the seminal legislation, New Zealand's Testator's Family Maintenance Act 1900, while its key substantive provision (that subsequently adopted by legislatures throughout the Commonwealth) had a general elasticity which could accommodate different and potentially conflicting interpretations - a tension which was heightened by the inclusion of the terms "adequate" and "proper" in virtual juxtaposition. While, however, the absence of clear direction from the legislature has done nothing to ameliorate the burden on successive generations of judges as they have embraced the task of defining the scope of the family protection jurisdiction, Gordon Bale's observation that "proper maintenance is a much less amorphous concept than a fair share of the

legislation"; Hughes v National Trustees Executors and Agency (1979) 143 CLR 134; Goodman v Windeyer (1980) 144 CLR 490; Singer v Berghouse (No2) (1994) 123 ALR 481.

99 Per Turner J in Re McGregor [1961] NZLR 1077.

100 In $\operatorname{Re} Z$ [1979] 2 NZLR 495 at 506.

101 Law Reform Commission of British Columbia - Report of Statutory Succession Rights (1983) Report No 70- reservation by Mr Arthur Close at p 153. 
estate" 102 is still well made. Whatever the attraction of any judicial gloss, it must never be allowed to detract from the requirement that the initial question to be answered in every application is a jurisdictional one (that is, did the deceased make adequate provision for the proper maintenance of the applicant?). It seems, however, that as the judiciary have placed more and more emphasis on assessing the "moral duty" of the testator, they have shifted their focus completely from the actual statutory provisions which they are called to interpret - after all

"[f]lights of judicial rhetoric [such as the moral duty of a wise and just husband and father] lend themselves to quotation more than colourless prose - so much so that the statutory language is forgotten." 103

The unfortunate result is that the function of the legislation, admittedly never as transparent as it might have been, has become totally obscured.

It is submitted that this state of affairs cannot be remedied simply by enshrining the "moral duty" test in statute, as in the Republic of Ireland. Breach of moral duty is simply not the most satisfactory basis for judicial intervention in discretionary family protection systems, and is set to become even less satisfactory as we progress into the twenty-first century.

In the first instance, the concept itself is inherently too subjective, and will inevitably remain so - no matter how often judges declare, as, for example, the Irish judiciary have, ${ }^{104}$ that they are applying the test "objectively". Any given individual's (and every judge's) conception of moral duty will vary depending on factors such as age, social background, personal experience and religious beliefs. Furthermore, the Commonwealth courts have endorsed an "ambulatory" approach to the concept, acknowledging that changing social attitudes will have an influence on the existence and extent of moral duties. ${ }^{105}$ For example, in Australia it has been said that the judiciary are required:

"to apply prevailing community standards of what is right and appropriate since it is by those standards that the content both of the moral duty owed by a just husband and father to his wife and children and of departures from it will be measured."

One wonders, however, whether such a "community standards" approach is realistic for the present multi-cultural postmodern societies, societies which are characterised by ever more complex social relationships, successive marriages, de facto unions and reconstituted families. It was surely no coincidence that it was in the 1960's that the Australasian and Canadian Courts first experienced major difficulties in applying the moral duty test consistently.

$102 \mathrm{G}$ Bale, op cit at $\mathrm{n} 78$ at $\mathrm{p} 314$.

$103 \mathrm{G}$ Bale, op cit at $\mathrm{n} 78$ at $\mathrm{p} 316$.

104 See $e g$ Keane J in Re JR (November 1979, unreported).

105 Re Wilson op cit at n 58. See also Little v Angus [1981] 1 NZLR 126 at 127 (NZ CofA). In relation to Canada, see Esson JA in Price v Lypchuk Estate 26 ETR 259 at 268 - one must discharge one's parental and marital duties "in accordance with a contemporary view of testamentary independence". 
Secondly, one must consider the much wider debate about whether it is appropriate for the law to be enforcing familial moral obligations, rather than leaving such complex issues where they were historically, "within the purview of theologians, philosophers and the individual conscience". ${ }^{106}$ Back in 1940 Canadian Mannie Brown analysed the judiciary's adherence to the Allardice moral duty approach as part of what he considered to be a much broader trend during the first half of this century of converting moral obligations into legal obligations whenever possible. ${ }^{107}$ At the cusp of the new century, however, a similar approach seems neither desirable nor desired - as Grainer has argued in an article based on her submissions to the New Zealand Law Commission, ${ }^{108}$ moral duties are often most effectively

controlled by social pressure.

Not unrelated to the earlier point that moral duty is inherently subjective, a recent study carried out by Finch and Mason in England ${ }^{109}$ suggests that it is virtually impossible to build social norms about family responsibility into inheritance laws, for the simple reason that there is no broad consensus regarding such responsibilities. Using a series of vignettes, Finch and Mason focused in particular "on the question of whether people generally endorse the view that the right to inherit should be based simply on genealogical ties, unconnected with any other patterns of responsibility within families (a model which we called the 'black box') or whether people generally think that the right to inherit to an extent can be earned through special commitments acknowledged and fulfilled." 110 Although some of their findings supported the 'black box' approach, that is, inheritance is not something to be earned, there were also indications that the idea of an implicit bargain within the family had not been completely rejected.

Finally, and most significantly, however, the fundamental problem in relation to adult children has been the failure of legislatures to define precisely on what basis the judiciary are to interfere with the deceased's testamentary provision and make an award in an applicant's favour. This problem cannot be addressed merely by enshrining the moral duty standard in statute, for breach of some undefined moral duty can never, by itself, provide a sufficiently rational foundation for a family protection jurisdiction. While purporting to rectify alleged failures of a deceased's parental duties the Australasian and Canadian Courts have been furthering one or more of several very distinct functions. Examples (a non-exhaustive list) include: providing barely subsistence level support; compensating for the deceased's lifetime of neglect; rewarding past services; remedying the deceased's procrastination in relation to updating his will; reimbursing the applicant's

106 Manitoba Law Reform Commission Report, op cit at n 80, at p 23.

107 M Brown, op cit at n 69 at 264.

108 V Grainer, "Is Family Protection a Question of Moral Duty?" (1994) 24 VUWLR 141.

109 See generally J Finch and J Mason, Negotiating Family Responsibilities (1993) and $\mathbf{J}$ Finch and $\mathbf{J}$ Mason, "Family Responsibilities and Inheritance in Great Britain", in M Maclean and J Kurczewski (eds), Families, Politics and the Law: Perspectives for East and West Europe (1994) Chapter 6, pp 97 -121. Grainer, ibid also referred to this research in her New Zealand context.

$110 \mathrm{Ibid}$, at 116. 
expenditure; acknowledging a blood relationship or a genealogical tie. While the courts in the Republic of Ireland have generally been unprepared to interfere with a testator's wishes quite so readily ${ }^{111}$ as their Commonwealth counterparts, illustrations can be found within the jurisprudence on section 117 of the Succession Act 1965 of awards made which further several of the objectives on the above list, for example: the reward of past services, ${ }^{112}$ compensating for past neglect ${ }^{113}$ and acknowledging the family relationship. ${ }^{114}$

During the 1970's and 1980's various Commonwealth law reform agencies undertook reviews of the operation of family protection legislation within their jurisdictions, including, inter alia, the position of mature child claimants. This process focused welcome attention on the very diffuse purposes which had been underpinning children's claims on their parents' estates. The response of both the Alberta Institute of Law Research and Reform $^{115}$ and the Law Reform Commission of Manitoba ${ }^{116}$ (recommendations which were subsequently enacted) ${ }^{117}$ was that family protection should be restricted to a support function and, on the basis that duties enforceable post mortem should not be inconsistent with those duties legally enforceable during the testator's lifetime, eligibility should be limited to minor children or those under twenty-three still in education or vocational training. However, elsewhere the broader moral duty approach was generally endorsed, expressly or implicitly, and there was little attempt to clarify the purposes or objectives of the legislation. ${ }^{118}$

Unless, however, the law defines clearly and precisely why a family protection award is being made in favour of a particular applicant and what function it is serving, the very future of the flexible restraint on testamentary freedom, a mechanism which, properly guided and controlled, can make a very useful and effective contribution to modern succession law, must be in

111 See generally, Brady, Succession Law in Ireland, (2nd ed, 1996) and for a more analytical approach to the earlier cases see Cooney, "Succession and Judicial Discretion in Ireland: the Section 117 Cases" (1980) Irish Jurist (ns) 66. A striking feature of the jurisprudence on $\mathrm{s} 117$ is the dearth of references to Commonwealth authorities - a phenomenon for which Kenny $\mathrm{J}$ is no doubt partly responsible with his comments in $\operatorname{Re} G M$ [(1972) 106 ILTR 82] that such cases were of little assistance to the Irish judiciary because the legislation which they were interpreting had a much broader remit than its Commonwealth equivalents in that it was not limited in its application to children who were dependent upon the testator. However, in light of the authorities discussed above, one must doubt the accuracy of this appraisal.

112 In the Estate of Matilda McGarry, dec'd, McGarry v Byrne (November, 1978, unreported).

113 HL v Governor and Company of the Bank of Ireland, (July 1978, unreported).

114 In the matter of the Estate of $J R$ (November 1979, unreported).

115 Family Relief Report No 29, 1978.

116 Op cit at n 80.

117 In Alberta by the Family Relief Act 1980; in Manitoba by the Dependants Relief Act 1990.

118 See, eg, Law Reform Commission of British Columbia, op cit at note 100 (subject to a powerful dissent by Arthur Close) and Law Reform Commission, New South Wales, Report on the Testator's Family Maintenance and Guardianship of Infants Act (1977). 
doubt. A concept such as "breach of moral duty" (or indeed, a "fair distribution of the estate") is too vague and nebulous to ensure that the purposes and effect of the law are clearly communicated to all concerned and meanwhile members of the judiciary are at liberty to hide behind this rhetoric, giving frequent assurances that they have no power to recast unjust wills to effect a more equitable distribution - and then proceeding to do just that. In light of the current state of the authorities in some of the jurisdictions considered above, it is no exaggeration that Allardice, as subsequently applied, has transmuted the right of an adult child to ask for "proper maintenance" from his or her deceased parent's estate, into a right to receive a fair share of that estate in the absence of any direct evidence of justification for disinheritance. Such judicial metamorphosis of a statutory provision without the sanction of the legislature clearly goes beyond the proper role of the court in relation to either the interpretation and application of statutes, or the exercise of discretion.

\section{NEW ZEALAND - LEADING THE WORLD ONCE MORE?}

Any clarification and subsequent reformulation of the objectives of family protection legislation cannot, however, be undertaken in a vacuum, but must take place in tandem with an appraisal of other legal mechanisms through which persons may secure a share of a deceased's estate. For instance, if family protection for child applicants is to be restricted to a support function there undoubtedly will exist a "gap" - even jurisdictions which have adopted this narrow approach, such as Manitoba, recognise that non-dependent adult children may sometimes be entitled to part of an estate, for example, where a child has worked for his or her parent for virtually no wages. How should these issues be addressed - through the general law of trust, contract and estoppel, or by the introduction of a specific statutory remedy?

With its draft Succession (Adjustment) Act, ${ }^{119}$ the most serious attempt to date to overhaul and streamline the entire area of testamentary claims, New Zealand again appears to be leading the common law world in family inheritance matters. This Act, currently being considered by the New Zealand Parliament, proposes the abolition of the moral duty test and the introduction of two distinct types of claim - support claims, recognising dependency on the testator which should continue beyond the grave, and property division/contribution claims. Children would be able to make a support claim (to be supported for their reasonable needs in life) if they are minors, or under twenty-five and undertaking educational or vocational training, or unable to earn a reasonable, independent livelihood because of a physical, intellectual or mental disability which occurred before they reached twenty-five. ${ }^{120}$ Following considerable consultation and discussion, it has been proposed that adult independent children may also make a support claim, in their case described as a "needs claim", to provide them with the necessities of life - but only where they are genuinely in need and it is

119 In August 1996 the New Zealand Law Commission published Succession Law: A Discussion Paper (NZLC PP 24, 1996). This was followed by a Report, Testamentary Claims (Report 39) published in August 1997 and containing a draft Succession (Adjustment) Act. This Act has not yet been enacted.

120 Draft Succession (Adjustment) Act, s 27. 
possible, without unfairness to those otherwise entitled to the estate, to provide periodic payments sufficient to alleviate their need. ${ }^{121}$

In addition, it is proposed that children (and anyone else) may make a contribution claim where they are seeking the return of unremunerated benefits which they have conferred on the testator. Such claims, which are designed to replace the existing "mosaic of statute law, common law and equity"122 (namely contract, trusts, estoppel, restitution and the Law Reform (Testamentary Promises) Act 1949, New Zealand's unique statutory machinery for determining claims by persons who have contributed valuable benefits to the deceased), will be able to be brought where the applicant provided a benefit to the deceased during his or her lifetime and either the deceased expressly promised to make provision for the applicant in return for the benefit, or it is unjust for the estate to retain the benefit without making provision for the applicant. ${ }^{123}$ It is impossible to discuss these proposals in detail in this article, but suffice it to say, at this juncture, that any attempt to separate out the various functions of testamentary claims can only be a significant improvement on the current situation.

Before concluding it may be appropriate to mention briefly two family protection jurisdictions which have thus far been conspicuous by their absence, namely England and Northern Ireland. Their exclusion is justified by the subject-matter - Allardice's judicious father has not been invoked, at least overtly, by either the English judiciary when determining whether a testator has "failed to make reasonable financial provision" for the "maintenance" of his children under section 3 of the Inheritance (Provision for Family and Dependants) Act 1975, or by their Northern Ireland counterparts when exercising their comparable jurisdiction which is conferred by article 5 of the Inheritance (Provision for Family and Dependants)(Northern Ireland) Order 1979. It is interesting, however, that the existence of a "moral obligation" owed by the deceased to the applicant has been an influential factor in relation to adult child claimants in both of these jurisdictions. ${ }^{124}$ The more objective criteria of the 1975 Act and 1979 Order have generally resulted in much less uncertainty and inconsistency in relation to adult children than that which exists in the juridictions discussed earlier, but evidence can still be found within the reported case law of awards made which clearly further a "fair distribution of the estate" function rather than a support function. ${ }^{125}$ This is particularly so in Northern Ireland, where adult children have been treated more generously than in England, ${ }^{126}$

$121 \mathrm{Ibid}, \mathrm{s} 29$. Such an award may only be made out of the residue of the estate. There is also a facility for adult children to seek a chattel of modest value as a keepsake from their parent's estate (known as a "memento claim"): s 30. A quick procedure through the Disputes Tribunal is provided for such memento claims.

122 New Zealand Law Commission Report Number 39 (1997), Testamentary Claims, at $\mathrm{p} 13$.

123 Ibid, s 30.

124 In England, see in particular Re Coventry [1980] Ch 461, although more recently "moral obligation" has tended to be replaced by "special circumstances" - see Re Hancock [1998] 2 FLR 348, and Espinosa v Bourke [1999] 1 FLR 747.

125 In England see eg Re Leach [1986] Ch 226 and Re Goodchild [1996] 1 WLR 694 both of which were influenced by the source of the deceased's money.

126 Re McGarrell [1983] 8 NIJB and Re Creeney [1984] NI 397. 
generating both confusion and unpredictability, and, to the author's personal knowledge, a number of ex gratia settlements made out of estates to persons whose claim under the 1979 Order could at best be described as weak. The problems which Allardice and its aftermath have forced New Zealand to address are not without relevance to the discretionary family protection mechanisms of England and, more especially, of Northern Ireland.

\section{CONCLUSION}

The issues which have been under discussion in this article are, of course, part of a much broader debate about the position which children should occupy in a modern family property system, in an era in which inheritance laws have been characterised by the movement away from blood relatives in favour of the spouse ${ }^{127}$ and in which the most valuable intergenerational transfer may be an education (and the resultant earning capacity) rather than the family patrimony. ${ }^{128}$ Indeed, the focus in recent decades on the property interests of the wife (and, of course, her de facto counterpart) has undoubtedly diverted interest away from non minor children. Few would dispute that a spouse's claim on the family assets, both in life and on death, is paramount (or that the law's recognition of this fact was long overdue), but there are still a number of issues relating to the interests of other 'family members' (howsoever this class should be defined in the new millennium), which also deserve to be addressed. One of these is which, if any, circumstances, duties, or responsibilities relating to an adult child should be translated into proprietary interests in his or her deceased parent's estate? And, then, by virtue of what legal mechanism - a discretionary family protection system, or otherwise? To highlight just one issue which is of increasing concern, what of carers (a group including, but obviously much wider than, adult children)? With increased longevity and the acknowledgement throughout the western world that public funds will not be sufficient to care for an elderly population - who will be expected to care, and what part, if any, should inheritance play in the equation?

Allardice v Allardice has undoubtedly secured its place in the history of family property. Undoubtedly, also, its legacy will continue to be felt, not least on these shores, well into the twenty-first century. The manner in which it has shaped family inheritance law is not, however, without a number of difficulties. Like New Zealand other jurisdictions might benefit from a thorough appraisal of the functions and application of their family protection legislation and, in particular, its relationship to the rest of the family property regime.

127 See generally MA Glendon, The Transformation of Family Law (1989), and MA Glendon, State, Law and Family (1977) pp 279-280.

128 See generally Langbein, "The Twentieth-Century Revolution in Family Wealth Transmission" (1988) 86 Mich LR 722. 